\title{
Climatological perspectives of air transport from atmospheric boundary layer to tropopause layer over Asian monsoon regions during boreal summer inferred from Lagrangian approach
}

\author{
B. Chen ${ }^{1}$, X. D. Xu' ${ }^{1}$, S. Yang ${ }^{2}$, and T. L. Zhao ${ }^{3}$ \\ ${ }^{1}$ State Key Laboratory of Severe Weather, Chinese Academy of Meteorological Sciences, Beijing, 100081, China \\ ${ }^{2}$ Laboratory of Cloud-Precipitation Physics and Severe Storms (LACS), Institute of Atmospheric Physics, \\ Chinese Academy of Sciences, Beijing, 100029, China \\ ${ }^{3}$ Key Laboratory for Atmospheric Physics and Environment, CMA-Nanjing University of Information Science \& Technology, \\ Nanjing, Jiangsu, 210044, China \\ Correspondence to: X. D. Xu (xuxd@cams.cma.gov.cn)
}

Received: 25 November 2011 - Published in Atmos. Chem. Phys. Discuss.: 6 February 2012

Revised: 6 June 2012 - Accepted: 13 June 2012 - Published: 6 July 2012

\begin{abstract}
The Asian Summer Monsoon (ASM) region has been recognized as a key region that plays a vital role in troposphere-to-stratosphere transport (TST), which can significant impact the budget of global atmospheric constituents and climate change. However, the details of transport from the boundary layer (BL) to tropopause layer (TL) over these regions, particularly from a climatological perspective, remain an issue of uncertainty. In this study, we present the climatological properties of BL-to-TL transport over the ASM region during boreal summer season (JuneJuly-August) from 2001 to 2009. A comprehensive tracking analysis is conducted based on a large ensemble of TSTtrajectories departing from the atmospheric $\mathrm{BL}$ and arriving at TL. Driven by the winds fields from NCEP/NCAR Global Forecast System, all the TST-trajectories are selected from the high resolution datasets generated by the Lagrangian particle transport model FLEXPART using a domain-filling technique. Three key atmospheric boundary layer sources for BL-to-TL transport are identified with their contributions: (i) $38 \%$ from the region between tropical Western Pacific region and South China Seas (WP) (ii) $21 \%$ from Bay of Bengal and South Asian subcontinent (BOB), and (iii) $12 \%$ from the Tibetan Plateau, which includes the South Slope of the Himalayas (TIB). Controlled by the different patterns of atmospheric circulation, the air masses originated from these three source regions are transported along the different tracks into the TL. The spatial distributions of three source regions
\end{abstract}

keep similarly from year to year. The timescales of transport from BL to TL by the large-scale ascents r-range from 1 to 7 weeks contributing up to $60-70 \%$ of the overall TST, whereas the transport governed by the deep convection overshooting become faster on a timescales of 1-2 days with the contributions of $20-30 \%$. These results provide clear policy implications for the control of very short lived substances, especially for the source regions over Indian subcontinent with increasing populations and developing industries.

\section{Introduction}

Troposphere-stratosphere air mass exchange significantly impacts the distribution and variation of atmospheric composition in stratosphere. The changes of atmospheric tracer constituents in stratosphere, such as ozone, water vapor, cirrus cloud, aerosol particles, can impose a substantial effect on global climatic change by regulating its photochemistry and radiation balance processes (e.g. Forster and Shine, 1999; Johnson et al., 2001; Stohl et al., 2005; Liu et al., 2005; Chen et al., 2006; Solomon et al., 2010; Sherwood et al., 2010). This significance is of great importance for understanding climate change (Holton et al., 1995; Stohl et al., 2003).

Asian Summer Monsoon (ASM) region is of particular interest in upwelling polluted air from boundary layer air into the free troposphere, reaching the upper troposphere and the

Published by Copernicus Publications on behalf of the European Geosciences Union. 
stratosphere. It has been revealed that the upwelling results from the interaction of active deep convections within the troposphere and strong anticyclonic flow over the tropopause (Lawrence, 2011). The upwelling can feed stratospheric circulation cells over vast areas of the tropics and subtropics, which thereby exerts extensive effects on the composition of the global stratosphere. Satellite observations and in-situ measurements found a persistent anomaly chemical concentration distribution of tracer gases between the upper troposphere and the lower stratosphere monsoon anticyclone during the summer season over the ASM region (e.g. Oltmans et al., 2001; Fu et al., 2006; Jiang et al., 2007; Park et al., 2007, 2008, 2009; Barret et al., 2008; Tian et al., 2008; Pan et al., 2010; Randel et al., 2010), representing a monsoon "signature" for chemical constituents. Jacob and Winner (2009) suggested that the contribution of TST over the Indian subcontinent is an order of magnitude larger than that over Europe, mid-latitude North America. A modeling study by Gettelman et al. (2004) presented that the air transport within the ASM anticyclone could account for as much as $75 \%$ of the total net upward water vapor flux in the tropics at tropopause levels during summer season. Source analyses of stratospheric water vapor also indicated that the entry of water vapor into the stratosphere over the east and southern parts of ASM region are main contributors to the moist phase of tropical tape recorder (Dethof et al., 1999; Dessler and Sherwood, 2004; Bannister et al., 2004; Fueglistaler et al., 2005). Another issue that should be pointed out is that the East and South Asia is currently the fastest growing economy region with the densest population in the world. The increasing emissions over Asia may have significant influences on the transport of air pollutants over the ASM region (Lawrence, 2011), with the warming and moistening air entering the stratosphere $(\mathrm{Su}, 2011)$. The increasing emission will impose an additional burden for the air pollutant TST.

The investigation on the Boundary Layer to Tropopause Layer (BL-to-TL) air mass transport over the ASM region is of particular importance for the understanding of atmospheric composition distribution, the global radiation budget and the stratospheric tracer prediction at the global scale. This research hotspot has attracted considerable meteorological interest (e.g. Bannister et al., 2004; Gettelman et al., 2004; Fu et al., 2006; Li et al., 2005; Randel and Park, 2006; Park et al., 2007, 2008, 2009; Tian et al., 2008; Lawrence and Lelieveld, 2010; Randel et al., 2010; Jiang et al., 2007; Duflot et al., 2010; Baker et al., 2011; Lawrence, 2011). The TST could be behaved driven by the vertical transport of lower tropospheric pollutants in deep convection associated with the monsoon circulation (Bannister et al., 2004; Fu et al., 2006; Randel and Park, 2006) and confinement within the strong monsoon anticyclone in the lower stratosphere (James et al., 2008; Park et al., 2008, 2009). The air mass TST is found over Indonesia, the west Pacific and Tibet Plateau regions (Holton and Gettelman, 2001; Fueglistaler et al., 2004).
However, in respect of the transport processes and its mechanisms, a set of the comprehensive properties of BLto-TL transport over the ASM region are poorly quantified or remain controversial. One of the most important questions is: from which geographical locations does the BL air reaching the TL originate? In particular, do regions with strong uplifts of BL air coincide with the source regions emitting very short lived substances (VSLS)? In fact, impacts of cross tropopause transport on the chemical nature of the lowermost stratosphere depend critically on the nature of chemical sources in those regions (Hoor et al., 2010). The distribution of source regimes and differences between them may have much larger implications for other chemical species, such as very short-lived bromine compounds (Sinnhuber and Folkins, 2006; Levine et al., 2007), or hydrogen cyanide (Randel et al., 2010). Based on the analysis of satellite observations, Fu et al. (2006) showed that deep convection over the Tibetan Plateau and south slope of the Himalayas is a substantial source of water vapor to the local lower stratosphere. They further suggested that transport from convection over this region could represent a short circuit of the tropical tropopause cold trap, thereby supplying relatively moist air to the global stratosphere. Park et al. (2009) conducted "tagged" sensitive simulation analyses and identified an effective pathway for surface pollution from Asia, India, and Indonesia to enter the global stratosphere. Other studies (Park et al., 2007; James et al., 2008; Devasthale and Fueglistaler, 2010) also confirmed that Tibetan plateau may play only a second role in TST transport compared to BOB.

Additionally, another major area of uncertainty is to quantify the transport timescale, as the efficiency in air transport across the TL is critically determined by both the local overshooting of deep convection and the large-scale ascent. Modeling suggested that deep convection could efficiently lift human-derived species from strong source regions over Asia (Fu ea al., 2006; Dessler and Sherwood, 2004; Lawrence and Lelieveld, 2010). The slower ascent of convective outflow from lower altitudes could also play an important role, although large uncertainties in vertical velocities for the stratosphere prevent a definitive judgment (Park et al., 2007; James et al., 2008; Devasthale and Fueglistaler, 2010). However, an impact of those sources on stratospheric chemistry over Asian regions is closely related to transport timescales. The VSLS over those sources could be rapidly enough uplifted and reached the TL with a timescale shorter than their chemical lifetimes. Therefore, examining transport timescales from $\mathrm{BL}$ to $\mathrm{TL}$ as an important fundamental question is another objective of our study.

Furthermore, most previous studies on characteristic of TST over ASM region were generally limited to the distinct or shorter time period. Given the increasing pollutant emission for Asian region, there is an urgent need to overall characterize the BL-to-TL transport, particularly in a climatology view with a higher temporal and spatial resolution. In this study, we extend previous studies restricted to short and 
distinct time period to a climatological view on BL-to-TL air mass transport within ASM region during boreal summer season (JJA). In developing the "climatological" characteristics of BL-to-TL transport, we particularly focus on two following questions: (1) where are the preferred regions and their relative contributions for BL-to-TL transport? and (2) what are detailed transport pathways and their associated timescales for the BL-to-TL transport of chemical species and their implications.

To achieve the goals of this study, a comprehensive analysis of trajectory-tracking of the TL -BL over the source regions was conducted in this study. The boundary layer sources are identified as the measure of the "density" of particles leaving the BL as in Berthet et al. (2007), allowing the importance of different emission regions of to be compared quantitatively. The trajectories analysis are based on the three-dimensional trajectory data sets generated by a fully Lagrangian transport and dispersion model (FLEXPART) covering a period of from 2001 to 2009. The FLEXPART model equipped with the reverse domain filling technique is driven by meteorological fields from NCEP/NCAR (National Centers for Environmental Prediction/National Center for Atmospheric Research) global forecasting system with a $1 \times 1$ latitude-longitude grid resolution on 26 vertical levels.

More details related to the methodology and data is presented in Sect. 2. Section 3 analyzes the results, including the principal surface sources and their relative contributions (Sect. 3.1), together with transport pathways (Sect. 3.2), transport timescales (Sect. 3.3) and an analysis of its annual variability (Sect. 3.4). Section 4 concludes a summary of this study.

\section{Model and methodology}

\subsection{Trajectory model FLEXPART}

Based on meteorological analyses, the approach of Lagrangian trajectories has been widely used in the studies of the trace substance transport, especially on the air mass source/sink analyses (Stohl and James, 2004; Fueglistaler et al., 2004, 2005; Berthet et al., 2007; Levine et al., 2007; James et al., 2008; Pfahl and Wernli, 2009; Chen et al., 2010; Clain et al., 2010; Knippertz and Wernli, 2010; Law et al., 2010; Ryoo et al., 2011; Hoor et al., 2010; Tzella and Legras, 2011). Although previous trajectory-based studies have shown the high potential of this method, most of these works were restricted to case studies and none of them has paid special attentions to ASM region.

Herein, we make use of the Lagrangian particle dispersion model FLEXPART (Stohl et al., 2005; Forster et al., 2007; Stohl and Sodemann, 2010). The FLEXPART calculates the trajectories of so-called tracer particles using the mean winds interpolated from the analysis fields and the parameterizations representing turbulence and convective transport. These processes, which are not included in standard trajectory models, are important for a realistic simulation of the trace substance transport (Stohl et al., 2005). Including these factors makes the calculations more computationally demanding and the statistical analysis of the model results more complex. In general terms, the FLEXPART model is accurate to simulating long-range and mesoscale transport, diffusion and radioactive decay of tracers released from a source as well as dry and wet depositions. More recently, this model has been used to successfully simulate stratosphere-troposphere transport and the associated studies (James et al., 2003; He et al., 2011; Werner et al., 2010; Paris et al., 2010; Vogel et al., 2011; Ryoo et al., 2011; Hirdman et al., 2010; Schmale et al., 2011).

\subsection{Methodology}

Similar to the work by Stohl (2010), a "domain filling" option is adopted for the initialization of the FLEXPART model, so that the whole column atmosphere over ASM region $\left(40-160^{\circ} \mathrm{E} ; 0-60^{\circ} \mathrm{N}\right)$ is "filled" homogeneously with 2.2 millions particles representing the total atmospheric mass (each parcels roughly equal $7.0 \times 10^{11} \mathrm{~kg}$ ) with the year to year changes in the total atmosphere mass variability. Particles are then allowed to move freely driving by meteorological fields from the National Centers for Environmental Prediction/Global Forecast System (NCEP/GFS) with a resolution of $1 \times 1^{\circ}$ and 26 levels vertically extending from surface to $10 \mathrm{hPa}$ (see http://rda.ucar.edu/datasets/ds083.2/). The period of simulation is from 00:00 UTC, 1 May to 00:00 UTC 15 September for each year; however, the analyses are based on the model output from 1 June to 31 August (JJA). The model output information of particles including longitude, latitude, altitude, potential vortices, temperature and so on are recorded every $6 \mathrm{~h}$.

Our main aim is to determine and characterize the subensemble of trajectories departing the BL and arriving at the TL during their journey with the so-called, TST-trajectories ensemble. The TST-trajectories are selected and defined as those parcels departed from the atmospheric boundary layer and then undergo tropopause-crossing during the period from 1 June to 31 August (JJA) days forward tracking. Additionally, we apply a residence time criterion for the TSTtrajectory selection, namely, a trajectory is identified as a member of the TST-trajectories only if the air parcel retained in the stratosphere at least $24 \mathrm{~h}$ after the tropopause-crossing.

The PBL heights are calculated according to Vogelezang and Holtslag (1996) using the critical Richardson number concept. The PBL height is set to the height of the first model level for which the Richardson number exceeds the critical value of 0.25 . As to the tropopause definition, the dynamical tropopause is used in middle and high latitude, while thermal one in tropical region. In subtropics, linear interpolation method is adopted to get the hybrid tropopause. The dynamical tropopause refers to the potential vortices surface 


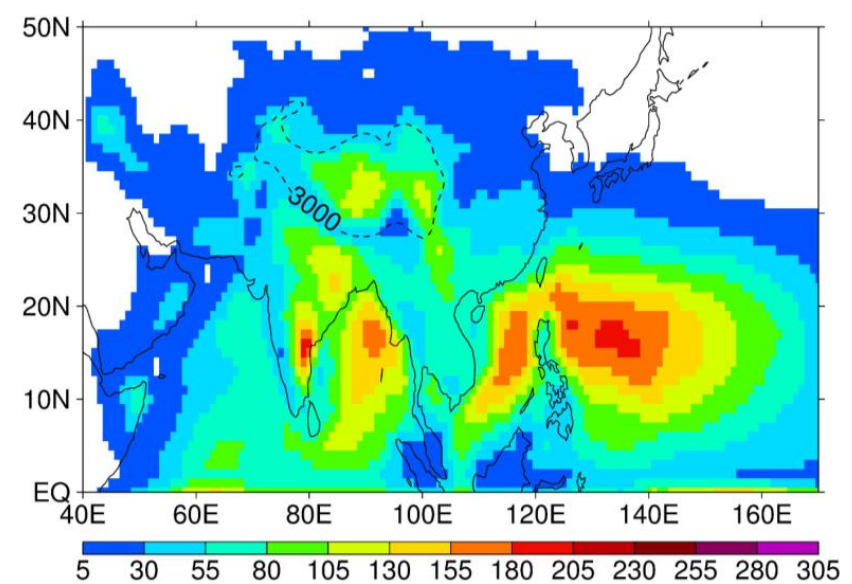

Fig. 1. Density field of numbers of all TST-trajectories in boundary layer in the $1 \times 1^{\circ}$ longitude-latitude bin averaged over June, July and August from 2001 to 2009. TST-trajectories are defined as the trajectories departing the boundary layer and arriving at the tropopause layer. Dash lines indicate the $3000 \mathrm{~m}$ topography height.

of $2 \mathrm{PVU}\left(1 \mathrm{PVU}=1.0 \times 10^{-6} \mathrm{~m}^{2} \mathrm{~s}^{-1} \mathrm{~K} \mathrm{~kg}^{-1}\right)$, and the thermal tropopause follows the definition of WMO (the height apart from ground more than $500 \mathrm{hPa}$, and with temperature lapse rate less than or equal to $2^{\circ} \mathrm{km}^{-1}$. More details could be found in technical note by Stohl et al. (2005).

In this case, the influence of winds turbulent on TST around the tropopause level is much weaker. We use the TST-trajectory ensembles to identify the source regions for air transport from BL into TL over ASM region. For characterization on the vertical entering the tropopause, we calculate the distribution of transport times for $\mathrm{BL}$ air reaching the tropopause for the first time. The distribution of TSTtrajectories from the originations is represented as a function of the transport times. In the following sections, we present and discuss the results of the TST-trajectories during the boreal summer season from 2001 to 2009.

\section{Results and discussions}

\subsection{Sources for transport of Boundary Layer Air into the Tropopause Layer}

The TST-trajectories can represent, to large extent, the BL-to-TL air mass transport during the simulation period and create a well resolved density field by aggregating all the trajectories to the appropriate $1 \times 1^{\circ}$ longitude-latitude "bin". Therefore, the density fields calculated for those TSTtrajectories can serve as a measure of the relative importance of different geographical regions as sources of BL air in the TST.

Figure 1 shows the multi-annual averaged density fields for the Northern Hemisphere summer seasons (JJA) of 20012009 over the ASM region illustrating the relative impor-

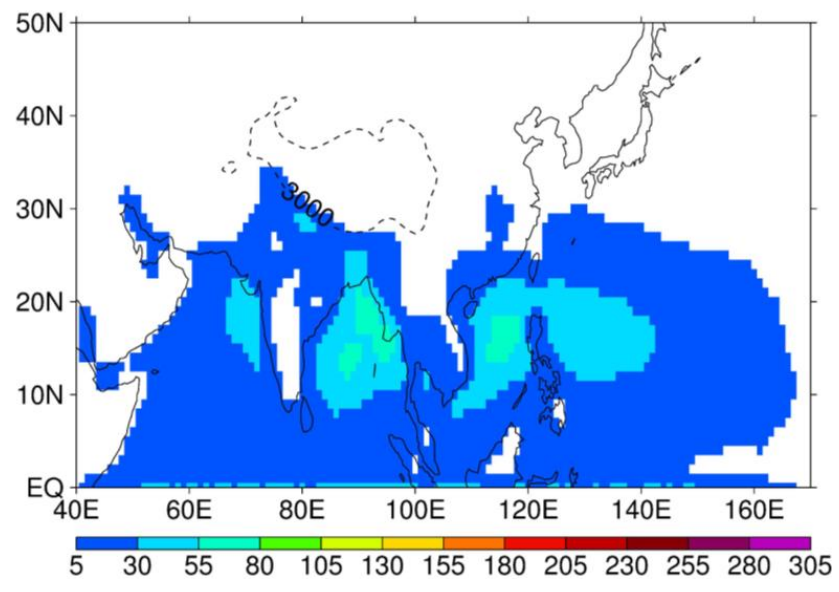

Fig. 2. Same as Fig. 1 but showing the density of trajectories departing from the $\mathrm{BL}$ and reaching the altitude at $18 \mathrm{~km}$.

tance of different geographical regions. The largest contribution of TST-trajectories is over the West Pacific region of $115-135^{\circ} \mathrm{E} / 20-40^{\circ} \mathrm{N}$ with $38 \%$ of the trajectory ensembles at the tropopause, followed by BOB of $115-135^{\circ} \mathrm{E} / 10-25^{\circ} \mathrm{N}$ with $\sim 21 \%$, and lastly with a contribution of $\sim 12 \%$ from TIB of $70-100^{\circ} \mathrm{E} / 30-40^{\circ} \mathrm{N}$. The integrated contribution of the WP, BOB, and TIB domains account as much as $71 \%$ of total TST over the ASM region, and the contribution from the rest of ASM region is insignificant. It is obviously seen that the distribution of sources characterized by strong geographical localization is consistent with the well-known locations of three distinct convective regimes over the ASM region (Wright et al., 2011). The WP is a low lying tropical domain characterized by large convective systems associated with the Asian monsoon, $\mathrm{BOB}$ is a maritime domain with the medium to large convective systems, whereas TIB is a mountainous, high altitude area with highly localized diurnal convective events occurring.

The most effective region for TST-trajectories into the stratosphere diagnosed here is quite in consistent with the study of Aschmann et al. (2009) showing that the region of Tropical western Pacific region and South China Seas accounted for about $55 \%$ of the bromine transported into the stratosphere under the supposition of a uniformly distributed source. Figure 1 also displays a small source contribution from TIB. This result is in contrast to the work by $\mathrm{Fu}$ et al. (2006) and Wright et al. (2011) who found that the contribution by Tibetan plateau is most important for TST. Nevertheless, our results are in agreement with other studies (Park et al., 2007; James et al., 2008; Devasthale and Fueglistaler, 2010), claiming that very deep convection over the Tibetan plateau is comparatively rare, with a minor role in TST transport compared to the WP and BOB.

Figure 2 further shows the density distribution of all TSTtrajectories reaching the altitude of $18 \mathrm{~km}$, a height generally above the local tropopause. Comparing to the TST 


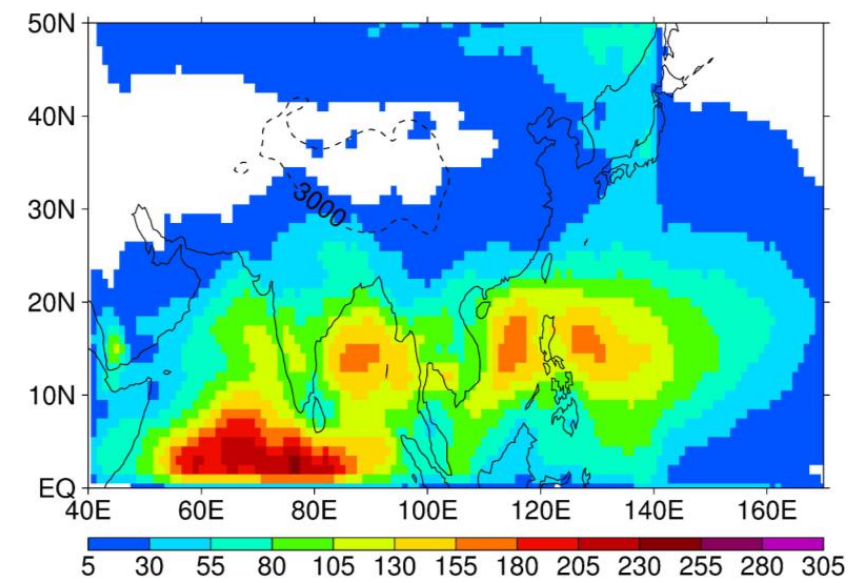

Fig. 3. The distribution of numbers of TST-trajectories on $1 \times$ $1^{\circ}$ longitude-latitude bin with the locations intersecting with the tropopause averaged for June, July and August from 2001 to 2009. Dash lines indicate the $3000 \mathrm{~m}$ topography height.

distribution at the tropopause in Fig. 1, we can find that the main source domains of Fig. 2 are mostly located at BOB and WP, specifically over China South Seas. It can be concluded that the convective sources entering the deep stratosphere are dominated over subtropical regions, rather than in Tibetan Plateau or its adjacent regions. This may be possibly attributed to the fact that the trajectories over Tibetan plateau are starting in relatively warm potential temperatures and at high elevations, as discussed by Berthet et al. (2007).

One thing that should be kept in mind is that trajectories do not can resolve all the scales of atmospheric circulation. Figure 1 could be viewed as climatology of source regions for transport from BL into TL, which might facilitate the quantitative understanding of relative importance of different source areas over the ASM region. Such a climatology is necessary to assess the chemical impact of pollutants, particularly in those sources located over the land where air trajectories connecting with the stratosphere are likely to be greatest important. It should be noted that, as a fast developing region with ever increasing air pollutant emission, the BOB, particularly the India subcontinent, could act as a leading role in atmospheric composition change assessment and climate prediction. The monsoon influence on stratosphere is expected to become increasingly important, given the ongoing growth of Asian emissions in the next decades (e.g. Su, 2011; Randel et al., 2010).

\subsection{Transport pathways}

Regarding to the details of transport pathways, Fig. 3 displays the distribution of the intersections of TST-trajectories with the tropopause, indicating the entry locations of TST for the whole ASM region. There is no doubt that the distribution of entry points at tropopause is large different from the BL source regions. The maximum entry pointes are lo- cated over the tropical Oceans $\left(0-10^{\circ} \mathrm{N}\right)$ in the southwest of India Ocean rather than WP region as shown in Fig. 1. This dramatical difference reflects that large number of trajectories undergoing convection or front uplift would experience a long distance horizontal transport before they enter the tropopause driven by large scale circulation, such as Asia anticyclone and tropical east jet. Figure 3 thus further emphasize the irreplaceable role of TST over the ASM region, in particular increasingly importance given the ongoing growth of Asian emissions.

From Fig. 3, it also can be found that there are two relative smaller maximum entry regions over the BOB and WP regions, which overlapped largely with the source domains as shown in Fig. 2. As pointed out in Sect. 2, these two sources domains are characterized by active convections. This indicates that the two regions would likely to inject directly much local BL air mass into stratosphere by substantial convection processes with a short timescale (Dessler and Sherwood, 2004), which will be discussed in the Sect. 3.3.

The comparison of distributions of boundary sources (Fig. 1) with mean distribution of locations of average the tropopause-crossing (Fig. 3) provides an ambiguous overview of pathways for the whole ASM region. Here we further classified the all TST-trajectories into three types corresponding to three main source regions defined in the previous sections. We examine their ensemble intersection locations with the representative altitudes of $8,12,14,16$, $18 \mathrm{~km}$ and on tropopause height, respectively. Figures 4, 5, and 6 present the distribution of the intersections for the TSTtrajectories at these altitudes for the regions BOB, WP and TIB, respectively. Overall, changes of distribution from the lower layer to higher layer roughly present a climatological view of transport pathways for TST-trajectories, although the 9-yr averaged distributions do not show the individual TSTtrajectories pathways. The large intersections concentrate on the BOB region (Fig. 4). This transport pattern is consistent with near-vertical convection. For the WP sources (Fig. 5), the spatial extent of those intersections regions expands with the increasing altitudes and is becoming less intense. However, compared to BOB and WP, the TST pathways for the trajectories over TIB seem to be characterized by a biggest spatial extension and dispersion. Differently to two source regions of $\mathrm{BOB}$ and $\mathrm{WP}$ with the stronger air mass transport into tropical areas, the air mass emitted from TIB are separated obviously into two parts, namely, one were exported to extratropical region of high latitude and the other transported into tropical regions (Fig. 6). The existence of systemic difference of transport pathways over these three sources induced not only by the geographic location of source regions but also the convection strength, which are controlled by the large scale atmospheric circulations.

For further investigation, we analyzed the mean horizontal circulation and vertical velocity field over ASM region for the same period using the NCEP/GFS datasets. The circulation is dominated by the Asian monsoon anticyclone, and 
(a) $8 \mathrm{~km}$

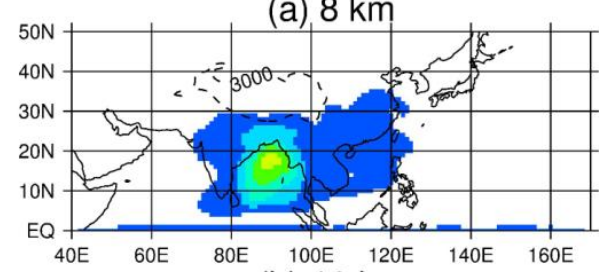

(b) $12 \mathrm{~km}$

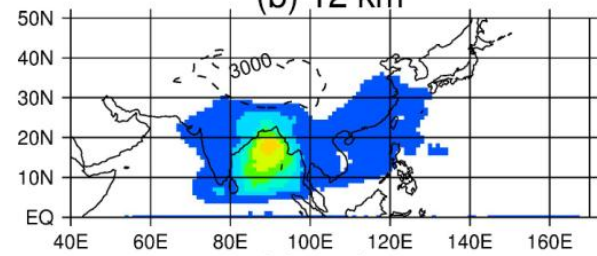

(c) $14 \mathrm{~km}$

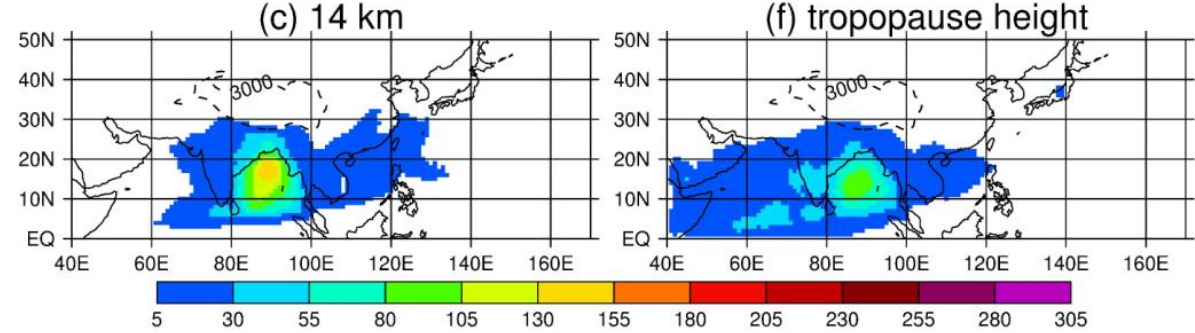

(d) $16 \mathrm{~km}$

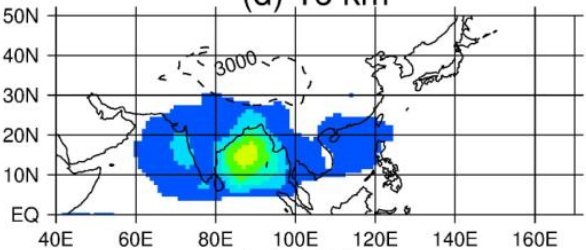

(e) $18 \mathrm{~km}$

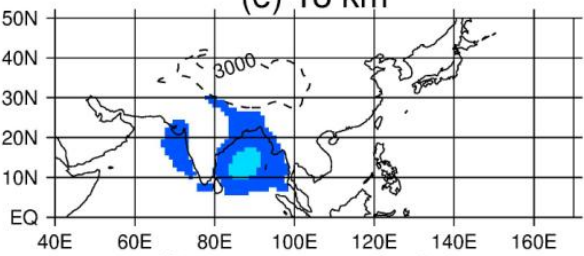

(f) tropopause height

Fig. 4. The intersections of TST-trajectories departing from BOB with the altitudes of (a) 8 , (b) 12 , (c) 14 , (d) 16 , (e) $18 \mathrm{~km}$ and (f) the tropopause height. TST-trajectories are defined as in the Sect. 2.

(a) $8 \mathrm{~km}$

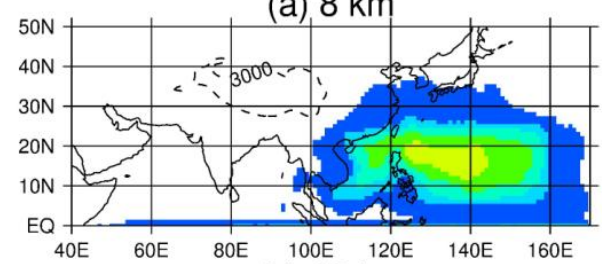

(b) $12 \mathrm{~km}$

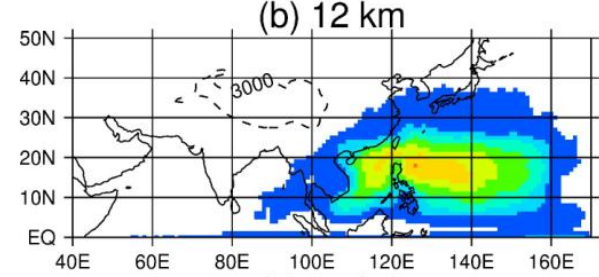

(c) $14 \mathrm{~km}$

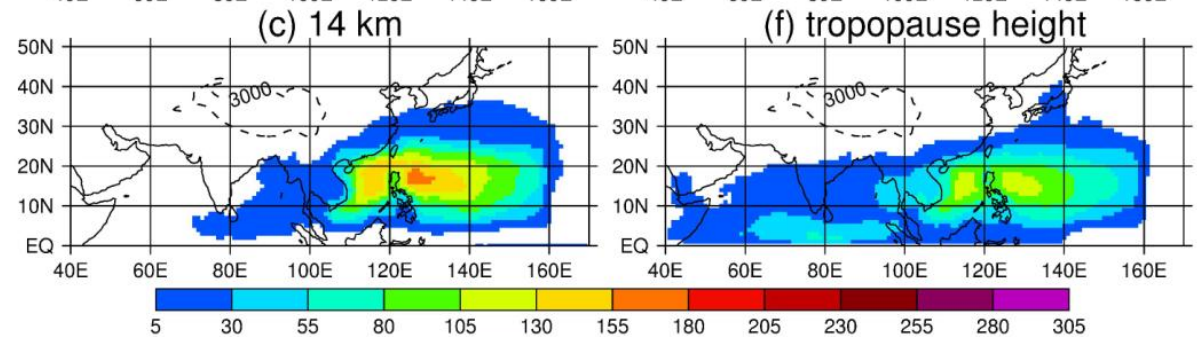

(d) $16 \mathrm{~km}$

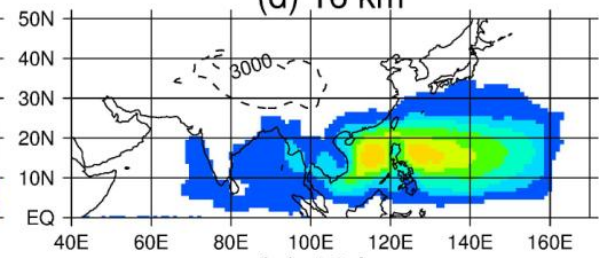

(e) $18 \mathrm{~km}$

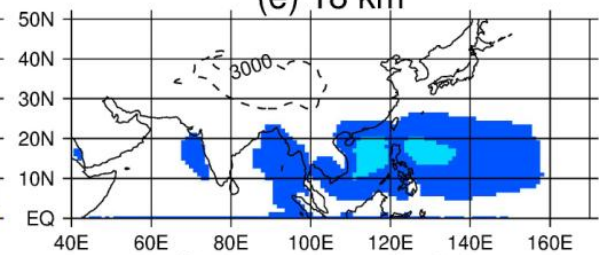

(f) tropopause height

Fig. 5. Same as Fig. 4, but for South China Seas and West Pacific Ocean.

the temperature field is characterized by a band of cold temperature. In the combination of Figs. 4, 5, and 6, one can obviously deduced that the continuous interaction between the large-scale ascents and the small-scale convection reach- ing the levels of tropopause provide an efficient route of TST from the atmospheric boundary to TL over the ASM region. Transport pathways from all three domains are dominated to varying degrees by convection activities and the Asian 
(a) $8 \mathrm{~km}$

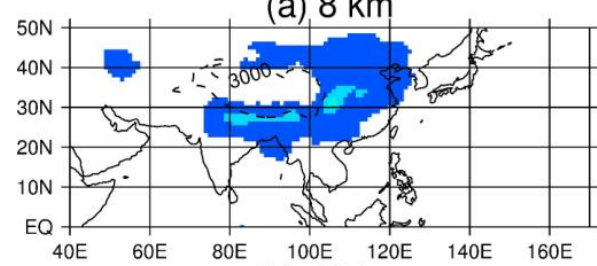

(b) $12 \mathrm{~km}$

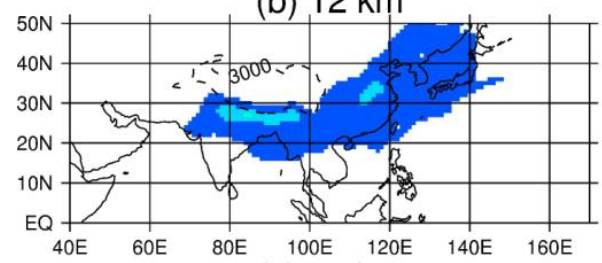

(c) $14 \mathrm{~km}$

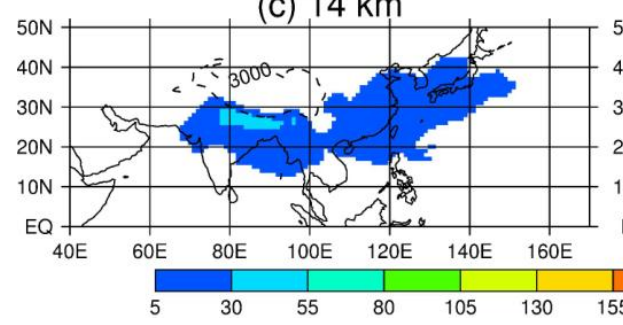

(d) $16 \mathrm{~km}$

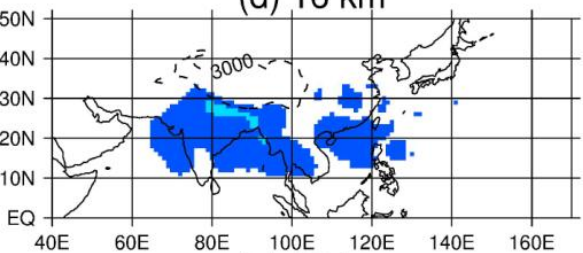

(e) $18 \mathrm{~km}$

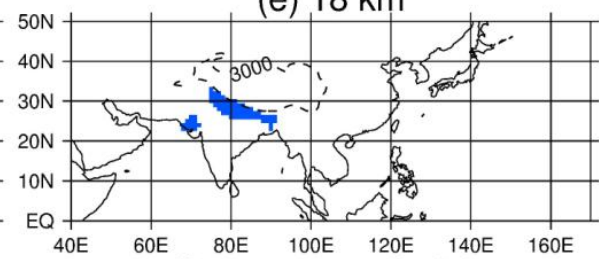

(f) tropopause height

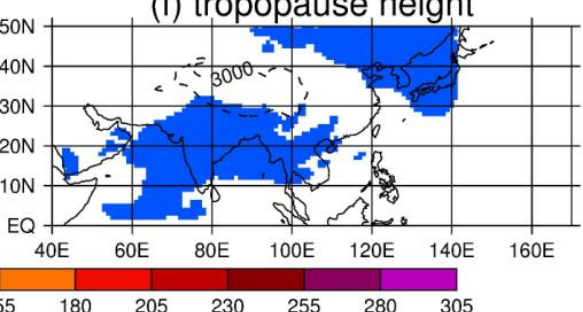

Fig. 6. Same as Fig. 4, but for Tibetan Plateau.

monsoon anticyclone. The reasons for these differences are apparent in the circulation characteristics of the monsoon anticyclone (Fig. 4) and the strength of convections of each domain. For instance, BOB trajectories are confined somewhat tightly by convection activities in low level and by central core of the anticyclone at $30^{\circ} \mathrm{N}$ and $60^{\circ} \mathrm{E}$ in the upper troposphere. TIB trajectories are uplifted and influenced by the two branch of the anticyclone, namely, the tropical east jet in south and the westward wind in north side. The pathways presented here support the founding of Dessler and Sherwood (2004), in which they claimed that monsoon air emitted from the near surface can bypass the tropical tropopause, and enter the stratosphere in the subtropics $\left(10-30^{\circ} \mathrm{N}\right.$ in boreal summer). Some of this air mass subsequently enters the tropics above the tropopause, and can be lifted into the stratosphere. This result can be easily judged from Figs. $4 \mathrm{f}, 5 \mathrm{f}$ and $6 \mathrm{f}$. Observations from satellites or in-situ measurements do not clearly indicate the pathway for TST, as they are restricted to the insufficient spatial resolution to resolve this transport process. This result would indicate a potential pathway for water vapor to enter the stratosphere without experiencing the cold trap in the tropical region, particularly in the Western Pacific. This might have a significant impact on water vapor content in stratosphere as discussed recently by Wright et al. (2011).

The NCEP/NCAR winds did not resolve all spatial scale transport processes, especially for the single deep cumulonimbus convection and turbulence-scale organization. Thus, the attention should be paid to Figs. 4, 5 and 6, which

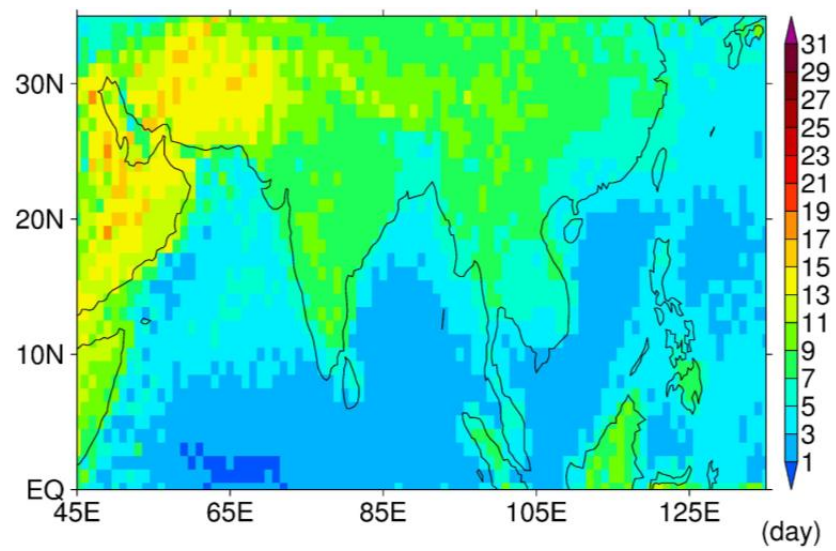

Fig. 7. The climatological mean spatial distribution of transport time for all TST-trajectories at tropopause.

are at least approximately correct and provide a better quantitative understanding of the transport pathways of air parcels. Regions of strong deep convection in the western tropical Pacific are characterized by correspondingly strong large-scale ascent in the NCEP/NCAR winds. Therefore, the pathways for the injection of BL air into the TL appear in trajectory calculations at least qualitatively correct.

\subsection{Timescales from the boundary sources to the TL}

The time lengths for TST-trajectories from the BL to the TL are obtained by forward tracking. Figure 7 shows the 

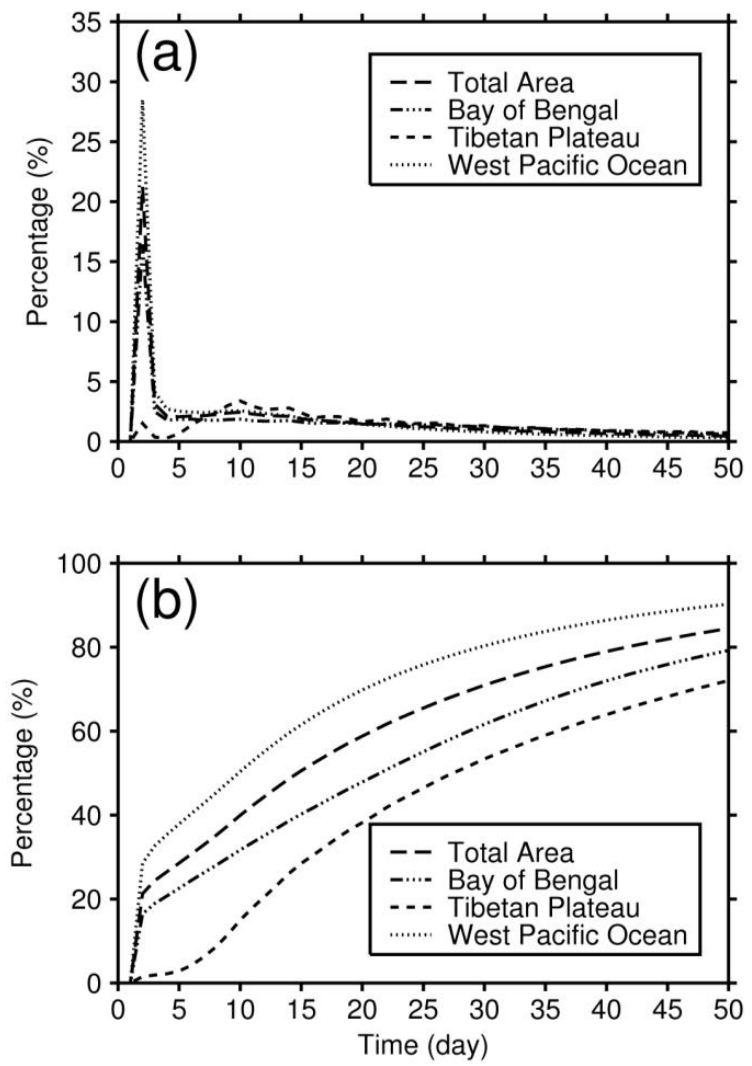

Fig. 8. (a) The frequencies and (b) cumulative distributions of the timescales for BL-to-TL transport in the different regions.

climatological mean spatial distribution of transport time for TST-trajectories at the tropopause. For large transit-times ( $>5$ days), the TST parcels are mostly distributed in the extra-tropics. The short timescale distributions are located in the ocean region (e.g. Bay of Bengal, Arab Sea and South China Seas), suggesting the direct convective injections into the TL in these areas. For the areas over land, the transport time becomes longer and is characterized by a timescale more than 5 days. Compared to the same latitudinal region, the west of Tibet Plateau and Indian subcontinent represent a shorter timescales. This indicates that deep convection over this region is most frequent in boreal summer season.

For further quantitative analysis, Fig. 8 presents the frequency and the cumulative distribution of the BL-to-TL transport timescales in summer season for the ASM regions and its sub-domains. Similar distributions are obtained for trajectories launched at different regions. The distributions are broad with decaying exponentially at large timescales.

A pronounced peak value frequency is located around 12 days (Fig. 8a). This suggests that a large fraction of air mass emitted in the BL can reach the TL with a relative short timescale. This timescale is quite consistent with the convective transport time obtained from previous modeling results by Fierli et al. (2011). Following the peak, an abrupt

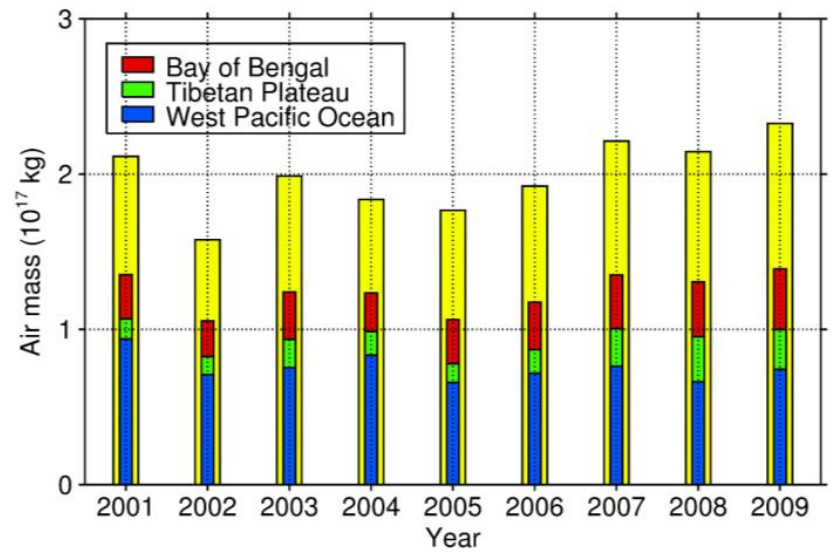

Fig. 9. Interannual variability of air mass transport from boundary layer into tropopause layer over the entire ASM regions of $40-$ $140^{\circ} \mathrm{E} / 0-40^{\circ} \mathrm{N}$ in yellow, WP of $115-135^{\circ} \mathrm{E} / 20-40^{\circ} \mathrm{N}$ in blue, $\mathrm{BOB}$ of $115-135^{\circ} \mathrm{E} / 10-25^{\circ} \mathrm{N}$ in red, and TIB of $70-100^{\circ} \mathrm{E} / 30$ $40^{\circ} \mathrm{N}$ in green.

decrease in number of TST-trajectory occurs with the increasing timescales. As shown in Fig. 8b, a larger amount of BL air mass can reach the TL in a range of longer than 5 days with a steady decreasing trend. The wide range is possibly caused by the large dispersion and confinement in the transport by the large-scale vertical circulations connecting to the unique monsoon anticyclone. Overall, these results are in agreement with the recent observational evidence that the most air entering into the tropical stratosphere are controlled not only by slow ascent large scale circulations but also by the convective injection (Schiller et al., 2009; Fierli et al., 2011; Corti et al., 2008).

It is difficult to thoroughly separate the convective transport from the large scale circulation transport. Some studies have attempted to quantify the relative roles of convection and large-scale ascent in determining upward BL-to-TL transport (Park et al., 2008; Kubokawa et al., 2010; Lawrence and Lelieveld, 2010). Nevertheless, Fig. 8b shows that approximately $20-30 \%$ of BL-to-TL transport is within $1-2$ days, whereas about one third of the transport by large scale circulation is roughly within $\mathbf{5 0}$ days. This result can serve as a qualitative assessment for their respective contribution, subjecting to the caveats regarding the trajectory calculations outlined by Levine et al. (2007) and Berrate et al. (2007). The validation of these results is beyond the scope of this study and will be conducted in another ongoing work using a cloud-resolving modeling.

For further comparison, we also calculated the transport timescales for the sources of BOB, TIB and WP separately (Fig. 8). The frequency distributions of timescales for TSTtrajectories over three sub-domain sources show the similar shape but with a slight variability in magnitude from one region to another. This small difference could be attributed to the differences of convection characteristics among these 

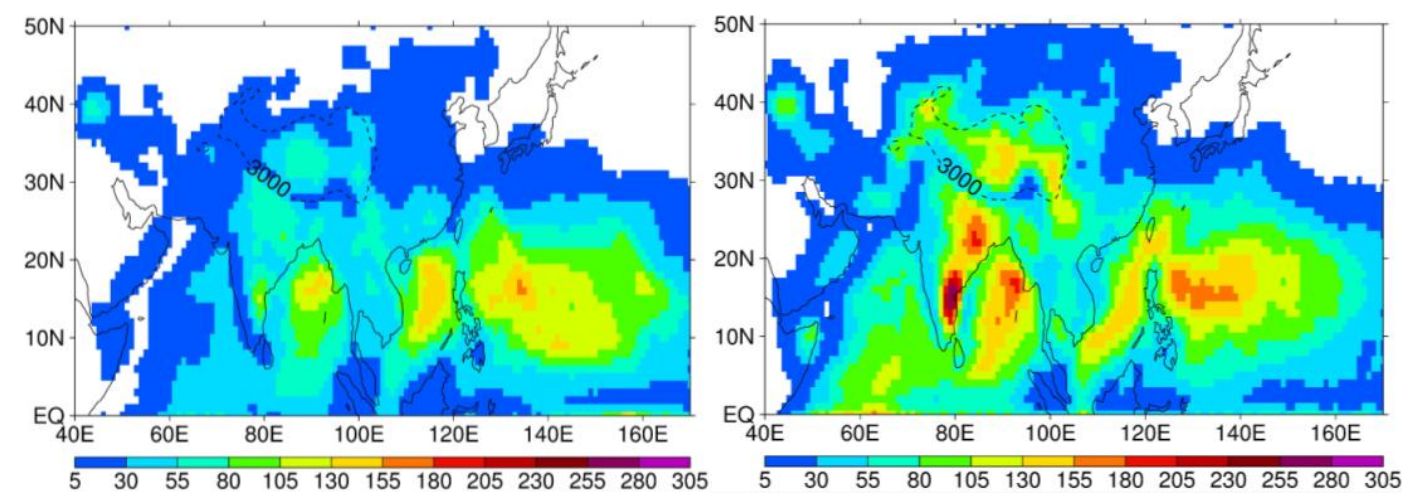

Fig. 10. Same as Fig. 1, but for the summer season of 2002 (left) and 2009 (right), respectively.

regions. Continental and marine convection over BOB and WP appear to play a more important role compared to the convection over TIB. The $28 \%$ of transport associated with convective timescale of shorter than approximately 2 days took place over the west Pacific, while transport over TIB with the same timescale almost could be ignored (less than $5 \%$ in 2 days). In summary, a large fraction of BL-to-TL transport is sufficiently rapid, especially over the WP and BOB regions, representing an important route of TST over the ASM region. However, regarding to the distribution of surface emissions, the TST over the WP may have less consequences on stratospheric chemistry than that over the BOB region where the huge human derived pollutants are increasingly emitted.

\subsection{Interannual variability}

Anomalies in the TST transport of individual summer might lead to a year-to-year variability of atmosphere compositions in UTLS associated with the intrinsic oscillation of large scale ASM circulations. Figure 9 shows the interannual variability of different BL sources over the entire ASM region. Apparently, three sub-domain sources show the similar pattern of year-to-year change in line with the bulk TST mass, particularly for WP and BOB. These points reinforce the leading role of $\mathrm{BOB}$ and WP source with respect to the variability of the whole summer TST within ASM region.

To further investigate the interannual variability, we calculated the density field of those trajectories that departed from the BL and subsequently arrived at tropopause layer for each summer form 2001 to 2009. The figures are shown as Supplement. Figure 10 only presents two density field for the summer of 2002 and 2009, respectively: a relatively weak year of TST and a stronger year according to Fig. 9 (The density field calculated for each summer of 2001 to 2009 is shown as Supplement). It can be obviously see that the intensities of $\mathrm{BOB}$ and TIB sources were much greater during the stronger year of 2009 than in the weaker year 2002, with the similarly high values completely absent in the TIB and BOB regions. However, WP remains the relatively weaker maximum distribution. The weak but detectable interannual variability promotes questions about the influence of large-scale climate modes on shifts in the BL sources. It should be noted that the 9-yr averaged trajectory data could not present the full influence of any anomalous climatic period. An analysis of the 9-yr time series can not reveal any significant correlations between BL source variability and either the western Pacific Ocean high or the El Niño/Southern Oscillation. On the basis of longer time series, this question could be answered by a more thorough analysis. Nevertheless, the slight difference between individual years emphasizes the robustness of the methodology and results presented here from another strategic point of view.

\section{Summary and conclusion remarks}

The monsoon circulation provides an effective pathway from atmospheric boundary layer (BL) in Asia, India, and Indonesia to the TL, the gateway to the stratosphere exerting a potential influence on global composition and climate in stratosphere. This influence on the stratosphere is expected to become increasingly important given that the Southern Asia is currently one in the most heavily populated regions of the world and the ongoing growth of Asian emissions in the next decades.

In this study the high resolution simulations based on a 3-D Lagrangian model FLEXPART driven by NCEP/GFS wind summer fields of 2001-2009 are conducted. All the selected TST-trajectories which are defined in term of departure from the atmosphere boundary layer and at last reaching the tropopause layer, were identified during the modeling period to make a climatology of BL-to-TL transport, focusing on the identification of the near surface sources and quantitative assessment of their relative contributions, the exactly pathways, and the transport timescales.

The source identifications from this study clearly show that the dominant source domains are located in Bay of Bengal and South Asian subcontinent (BOB), the Western Pacific and South China and Philippine Seas (WP), and the Tibetan 
Plateau and South Slope of the Himalayas (TIB). The contribution from the WP is the largest, following by BOB, with TIB the smallest. The results also show that the contribution of the boundary layer sources, especially for major polluted regions of India subcontinent directly contribute up to $20 \%$ of the air mass crossed the tropopause, whereas there are somewhat smaller contributions from another polluted region of Eastern China. This result provides clear policy implications for the control of very short lived substance emissions over these regions in future.

The gateways for stratosphere entry are localized over the Indian Ocean, Indonesia and the west Pacific, Also about one quarter of $\mathrm{BL}$ air that transported to the tropopause layer just above the region of the BL where it originated, indicating a strong connection between origin in the BL and entry into the TL associated with the directly local convection. The timescales of BL-to-TL air mass transported are less than 2 days by convections, while several weeks by large scale ascents. The air mass amount transport by direct convective injection is about one third of those by the large scale vertical circulations.

There are a number of limitations in this study. One most obvious limitation is connected with the utilized Lagrangian trajectory model and dataset. As discussed by Fueglistaler et al. (2005), a considerable uncertainty of represent physical transport processes in the atmosphere, due principally to the effects of unresolved motions and mixing events in trajectory approach. For instance, the deep convections especially in ASM region with vigorous convective activities could not be reflected in the NCEP/GFS data. On the other hand, an extremely conservative interpretation of our results is applied to "NCEP/GFS world". A systematic investigation of the NCEP/GFS data with focus on the influence of direct convective injection within the ASM region is still not available. An illustration on limitations of trajectory studies based on analyzed winds can also be found in work by Berthet et al. (2007).

Nevertheless, compared to standard trajectory models, FLEXPART model has its advantages in calculating the trajectories of so-called tracer particles using the mean winds interpolated from the analysis fields and parameterizations representing turbulence and convective transport. These considerations enable a more realistic simulation of the substances transport. The use of sufficiently long time periods also minimizes the effects of unrealistic turbulent fluctuations. Additionally, the comparative analyses from different datasets show a few fundamental characteristics of TST transport, indicating that the TST is not sensitive to the data choice as indicated by Wright et al. (2011). Furthermore, similar pattern of sources distribution and transport properties promote confidence in qualitative conclusions in this paper.

Accordingly, our results might be viewed as robust with respect to the BL-to-TL air mass transport over ASM region in a climatological sense, although subjected to the limitations, in particular, inherent to the experimental methodology and the realism of the wind field in NCEP/GFS dataset. In contrast to previous studies, this study presents a 9-yr tracking analysis. The results could potentially extend our current understanding on the BL-to-TL transport, and can facilitate the assessment of the impact of TST on the chemical tracer distribution in stratosphere, especially for the source regions of high residential Indian subcontinent with increasing populations and developing industry in future.

Further work requires the confirmation of these transport properties with other operational datasets. Higher resolution input data as the new ECMWF would be useful for further analysis, especially for small scale features. Additional validation with in situ observations or new satellite observations over the ASM region could also be critical for understanding the transport processes. Evaluations of a longer time period would also be useful for a more detailed analysis, especially when the projected large scale circulation changes are taken into account. The role of large scale ascent transport versus small scale convection transport will be examined in an ongoing follow-up study using cloud-resolving model.

\section{Supplementary material related to this article is available online at: http://www.atmos-chem-phys.net/12/ 5827/2012/acp-12-5827-2012-supplement.pdf.}

Acknowledgements. This research was jointly funded by the National Natural Science Foundation of China (Grant No. 41105027, 41130960), the China Postdoctoral Science Foundation (Grant No. 20110490488), the Key Project of Basic Scientific Research and Operation fund of the Chinese Academy of Meteorological Sciences (2011Z001), and the social commonweal profession research program of Ministry of Science and Technology of the People's Republic of China (GYHY201006009).

Edited by: X. Tie

\section{References}

Aschmann, J., Sinnhuber, B.-M., Atlas, E. L., and Schauffler, S. M.: Modeling the transport of very short-lived substances into the tropical upper troposphere and lower stratosphere, Atmos. Chem. Phys., 9, 9237-9247, doi:10.5194/acp-9-9237-2009, 2009.

Baker, A. K., Schuck, T. J., Slemr, F., van Velthoven, P., Zahn, A., and Brenninkmeijer, C. A. M.: Characterization of nonmethane hydrocarbons in Asian summer monsoon outflow observed by the CARIBIC aircraft, Atmos. Chem. Phys., 11, 503518, doi:10.5194/acp-11-503-2011, 2011.

Bannister, R. N., O'Neill, A., Gregory, A. R., and Nissen, K. M.: The role of the south-east Asian monsoon and other seasonal features in creating the "tape-recorder" signal in the Unified Model, Q. J. Roy Meteor. Soc., 130, 1531-1554, doi:10.1256/qj.03.106, 2004. 
Barret, B., Ricaud, P., Mari, C., Attié, J.-L., Bousserez, N., Josse, B., Le Flochmoën, E., Livesey, N. J., Massart, S., Peuch, V.H., Piacentini, A., Sauvage, B., Thouret, V., and Cammas, J.P.: Transport pathways of $\mathrm{CO}$ in the African upper troposphere during the monsoon season: a study based upon the assimilation of spaceborne observations, Atmos. Chem. Phys., 8, 3231-3246, doi:10.5194/acp-8-3231-2008, 2008.

Berthet, G., Esler, J. G., and Haynes, P. H.: A Lagrangian perspective of the tropopause and the ventilation of the lowermost stratosphere, J. Geophys. Res., 112, D18102, doi:10.1029/2006jd008295, 2007.

Chen, B., Xu, X. D., Bian, J. C., and Shi, X. H.: Irreversible stratosphere-troposphere mass exchange characteristics over the Asian summer monsoon region, Chinese J. Geophys.-Ch., 53, 1050-1059, doi:10.3969/j.issn.0001-5733.2010.05.005, 2010.

Chen, Y., Zhou, R., Shi, C., and Bi, Y.: Study on the trace species in the stratosphere and their impact on climate, Adv. Atmos. Sci., 23, 1020-1039, doi:10.1007/s00376-006-1020-3, 2006.

Clain, G., Baray, J. L., Delmas, R., Keckhut, P., and Cammas, J. P.: A lagrangian approach to analyse the tropospheric ozone climatology in the tropics: Climatology of stratosphere-troposphere exchange at Reunion Island, Atmos. Environ., 44, 968-975, doi:10.1016/j.atmosenv.2009.08.048, 2010.

Corti, T., Luo, B. P., de Reus, M., Brunner, D., Cairo, F., Mahoney, M. J., Martucci, G., Matthey, R., Mitev, V., dos Santos, F. H., Schiller, C., Shur, G., Sitnikov, N. M., Spelten, N., Vössing, H. J., Borrmann, S., and Peter, T.: Unprecedented evidence for deep convection hydrating the tropical stratosphere, Geophys. Res. Lett., 35, L10810, doi:10.1029/2008g1033641, 2008.

Dessler, A. E. and Sherwood, S. C.: Effect of convection on the summertime extratropical lower stratosphere, J. Geophys. Res., 109, D23301, doi:10.1029/2004jd005209, 2004.

Dethof, A., O’Neill, A., Slingo, J. M., and Smit, H. G. J.: A mechanism for moistening the lower stratosphere involving the Asian summer monsoon, Q. J. Roy. Meteor. Soc., 125, 1079-1106, 1999.

Devasthale, A. and Fueglistaler, S.: A climatological perspective of deep convection penetrating the TTL during the Indian summer monsoon from the AVHRR and MODIS instruments, Atmos. Chem. Phys., 10, 4573-4582, doi:10.5194/acp-10-45732010, 2010.

Duflot, V., Dils, B., Baray, J. L., De Mazière, M., Attié, J. L., Vanhaelewyn, G., Senten, C., Vigouroux, C., Clain, G., and Delmas, R.: Analysis of the origin of the distribution of $\mathrm{CO}$ in the subtropical southern Indian Ocean in 2007, J. Geophys. Res., 115, D22106, doi:10.1029/2010jd013994, 2010.

Fierli, F., Orlandi, E., Law, K. S., Cagnazzo, C., Cairo, F., Schiller, C., Borrmann, S., Di Donfrancesco, G., Ravegnani, F., and Volk, C. M.: Impact of deep convection in the tropical tropopause layer in West Africa: in-situ observations and mesoscale modelling, Atmos. Chem. Phys., 11, 201-214, doi:10.5194/acp-11201-2011, 2011.

Forster, C., Stohl, A., and Seibert, P.: Parameterization of Convective Transport in a Lagrangian Particle Dispersion Model and Its Evaluation, J. Appl. Meteorol. Climatol., 46, 403-422, doi:10.1175/jam2470.1, 2007.

Forster, P. M. d. F. and Shine, K. P.: Stratospheric water vapour changes as a possible contributor to observed stratospheric cooling, Geophys. Res. Lett., 26, 3309-3312, doi:10.1029/1999g1010487, 1999.

Fu, R., Hu, Y. L., Wright, J. S., Jiang, J. H., Dickinson, R. E., Chen, M. X., Filipiak, M., Read, W. G., Waters, J. W., and $\mathrm{Wu}, \mathrm{D}$. L.: Short circuit of water vapor and polluted air to the global stratosphere by convective transport over the Tibetan Plateau, P. Natl. Acad. Sci. USA, 103, 5664-5669, doi:10.1073/pnas.0601584103, 2006.

Fueglistaler, S., Wernli, H., and Peter, T.: Tropical troposphereto-stratosphere transport inferred from trajectory calculations, J. Geophys. Res., 109, D03108, doi:10.1029/2003jd004069, 2004.

Fueglistaler, S., Bonazzola, M., Haynes, P. H., and Peter, T.: Stratospheric water vapor predicted from the Lagrangian temperature history of air entering the stratosphere in the tropics, J. Geophys. Res., 110, D08107, doi:10.1029/2004jd005516, 2005.

Gettelman, A., Kinnison, D. E., Dunkerton, T. J., and Brasseur, G. P.: Impact of monsoon circulations on the upper troposphere and lower stratosphere, J. Geophys. Res., 109, D22101, doi:10.1029/2004jd004878, 2004.

He, H., Tarasick, D. W., Hocking, W. K., Carey-Smith, T. K., Rochon, Y., Zhang, J., Makar, P. A., Osman, M., Brook, J., Moran, M. D., Jones, D. B. A., Mihele, C., Wei, J. C., Osterman, G., Argall, P. S., McConnell, J., and Bourqui, M. S.: Transport analysis of ozone enhancement in Southern Ontario during BAQS-Met, Atmos. Chem. Phys., 11, 2569-2583, doi:10.5194/acp-11-25692011, 2011.

Hirdman, D., Sodemann, H., Eckhardt, S., Burkhart, J. F., Jefferson, A., Mefford, T., Quinn, P. K., Sharma, S., Ström, J., and Stohl, A.: Source identification of short-lived air pollutants in the Arctic using statistical analysis of measurement data and particle dispersion model output, Atmos. Chem. Phys., 10, 669-693, doi:10.5194/acp-10-669-2010, 2010.

Holton, J. R. and Gettelman, A.: Horizontal transport and the dehydration of the stratosphere, Geophys. Res. Lett., 28, 2799-2802, doi:10.1029/2001g1013148, 2001.

Holton, J. R., Haynes, P. H., McIntyre, M. E., Douglass, A. R., Rood, R. B., and Pfister, L.: Stratosphere-troposphere exchange Bradshaw, J. D. Davis, G. Grodzinsky, S. Smyth, R. Newell, S. Sandholm, and S. Liu (2000), Observed Distributions of Nitrogen Oxides in the Remote Free Troposphere From the Nasa Global Tropospheric Experiment Programs, Rev. Geophys., 38, 403-439, doi:10.1029/95rg02097, 1995.

Hoor, P., Wernli, H., Hegglin, M. I., and Bönisch, H.: Transport timescales and tracer properties in the extratropical UTLS, Atmos. Chem. Phys., 10, 7929-7944, doi:10.5194/acp-10-79292010, 2010.

Jacob, D. J. and Winner, D. A.: Effect of climate change on air quality, Atmos. Environ., 43, 51-63, doi:10.1016/j.atmosenv.2008.09.051, 2009.

James, P., Stohl, A., Forster, C., Eckhardt, S., Seibert, P., and Frank, A.: A 15-year climatology of stratosphere-troposphere exchange with a Lagrangian particle dispersion model: 1 . Methodology and validation, J. Geophys. Res., 108, 8519, doi:10.1029/2002jd002637, 2003.

James, R., Bonazzola, M., Legras, B., Surbled, K., and Fueglistaler, S.: Water vapor transport and dehydration above convective outflow during Asian monsoon, Geophys. Res. Lett., 35, L20810, doi:10.1029/2008g1035441, 2008.

Jiang, J. H., Livesey, N. J., Su, H., Neary, L., McConnell, J. C., and Richards, N. A. D.: Connecting surface emissions, 
convective uplifting, and long-range transport of carbon monoxide in the upper troposphere: New observations from the Aura Microwave Limb Sounder, Geophys. Res. Lett., 34, L18812, doi:10.1029/2007g1030638, 2007.

Johnson, D., Jucks, K., Traub, W., and Chance, K.: Isotopic composition of stratospheric water vapor: Implications for transport, J. Geophys. Res., 106, 12219-12226, 2001.

Knippertz, P. and Wernli, H.: A Lagrangian Climatology of Tropical Moisture Exports to the Northern Hemispheric Extratropics, J. Climate, 23, 987-1003, 2010.

Kubokawa, H., Fujiwara, M., Nasuno, T., and Satoh, M.: Analysis of the tropical tropopause layer using the Nonhydrostatic Icosahedral Atmospheric Model (NICAM): Aqua planet experiments, J. Geophys. Res., 115, D08102, doi:10.1029/2009jd012686, 2010.

Law, K. S., Fierli, F., Cairo, F., Schlager, H., Borrmann, S., Streibel, M., Real, E., Kunkel, D., Schiller, C., Ravegnani, F., Ulanovsky, A., D'Amato, F., Viciani, S., and Volk, C. M.: Air mass origins influencing TTL chemical composition over West Africa during 2006 summer monsoon, Atmos. Chem. Phys., 10, 10753-10770, doi:10.5194/acp-10-10753-2010, 2010.

Lawrence, M. G.: Atmospheric science: Asia under a high-level brown cloud, Nat. Geosci., 4, 352-353, 2011.

Lawrence, M. G. and Lelieveld, J.: Atmospheric pollutant outflow from southern Asia: a review, Atmos. Chem. Phys., 10, 1101711096, doi:10.5194/acp-10-11017-2010, 2010.

Levine, J. G., Braesicke, P., Harris, N. R. P., Savage, N. H., and Pyle, J. A.: Pathways and timescales for troposphere-to-stratosphere transport via the tropical tropopause layer and their relevance for very short lived substances, J. Geophys. Res., 112, D04308, doi:10.1029/2005jd006940, 2007.

Li, Q. B., Jiang, J. H., Wu, D. L., Read, W. G., Livesey, N. J., Waters, J. W., Zhang, Y. S., Wang, B., Filipiak, M. J., Davis, C. P., Turquety, S., Wu, S. L., Park, R. J., Yantosca, R. M., and Jacob, D. J.: Convective outflow of South Asian pollution: A global CTM simulation compared with EOS MLS observations, Geophys. Res. Lett., 32, L14826, doi:10.1029/2005g1022762, 2005.

Liu, X., Penner, J. E., and Herzog, M.: Global modeling of aerosol dynamics: Model description, evaluation, and interactions between sulfate and nonsulfate aerosols, J. Geophys. Res., 110, 137, 2005.

Oltmans, S., Johnson, B., Harris, J., Vömel, H., Thompson, A., Koshy, K., Simon, P., Bendura, R., Logan, J., Hasebe, F., Shiotani, M., Kirchhoff, V., Maata, M., Sami, G., Samad, A., Tabuadravu, J., Enriquez, H., Agama, M., Cornejo, J., and Paredes, F.: Ozone in the Pacific tropical troposphere from ozonesonde observations, J. Geophys. Res., 106, 32503-32525, 2001.

Pan, L. L., Bowman, K. P., Atlas, E. L., Wofsy, S. C., Zhang, F., Bresch, J. F., Ridley, B. A., Pittman, J. V., Homeyer, C. R., Romashkin, P., and Cooper, W. A.: The Stratosphere-Troposphere Analyses of Regional Transport 2008 Experiment, B. Am. Meteorol. Soc., 91, 327-342, doi:10.1175/2009bams2865.1, 2010.

Paris, J.-D., Stohl, A., Ciais, P., Nédélec, P., Belan, B. D., Arshinov, M. Yu., and Ramonet, M.: Source-receptor relationships for airborne measurements of $\mathrm{CO}_{2}, \mathrm{CO}$ and $\mathrm{O}_{3}$ above Siberia: a cluster-based approach, Atmos. Chem. Phys., 10, 1671-1687, doi:10.5194/acp-10-1671-2010, 2010.
Park, M., Randel, W. J., Gettelman, A., Massie, S. T., and Jiang, J. H.: Transport above the Asian summer monsoon anticyclone inferred from Aura Microwave Limb Sounder tracers, J. Geophys. Res., 112, D16309, doi:10.1029/2006jd008294, 2007.

Park, M., Randel, W. J., Emmons, L. K., Bernath, P. F., Walker, K. A., and Boone, C. D.: Chemical isolation in the Asian monsoon anticyclone observed in Atmospheric Chemistry Experiment (ACE-FTS) data, Atmos. Chem. Phys., 8, 757-764, doi:10.5194/acp-8-757-2008, 2008.

Park, M., Randel, W. J., Emmons, L. K., and Livesey, N. J.: Transport pathways of carbon monoxide in the Asian summer monsoon diagnosed from Model of Ozone and Related Tracers (MOZART), J. Geophys. Res., 114, D08303, doi:10.1029/2008jd010621, 2009.

Pfahl, S. and Wernli, H.: Lagrangian simulations of stable isotopes in water vapor: An evaluation of nonequilibrium fractionation in the Craig-Gordon model, J. Geophys. Res., 114, D20108, doi:10.1029/2009jd012054, 2009.

Randel, W. J. and Park, M.: Deep convective influence on the Asian summer monsoon anticyclone and associated tracer variability observed with Atmospheric Infrared Sounder (AIRS), J. Geophys. Res., 111, D12314, doi:10.1029/2005jd006490, 2006.

Randel, W. J., Park, M., Emmons, L., Kinnison, D., Bernath, P., Walker, K. A., Boone, C., and Pumphrey, H.: Asian Monsoon Transport of Pollution to the Stratosphere, Science, 328, 611613, doi:10.1126/science.1182274, 2010.

Ryoo, J.-M., Waliser, D. E., and Fetzer, E. J.: Trajectory analysis on the origin of air mass and moisture associated with Atmospheric Rivers over the west coast of the United States, Atmos. Chem. Phys. Discuss., 11, 11109-11142, doi:10.5194/acpd-11-111092011, 2011.

Schiller, C., Grooß, J.-U., Konopka, P., Plöger, F., Silva dos Santos, F. H., and Spelten, N.: Hydration and dehydration at the tropical tropopause, Atmos. Chem. Phys., 9, 9647-9660, doi:10.5194/acp-9-9647-2009, 2009.

Schmale, J., Schneider, J., Ancellet, G., Quennehen, B., Stohl, A., Sodemann, H., Burkhart, J. F., Hamburger, T., Arnold, S. R., Schwarzenboeck, A., Borrmann, S., and Law, K. S.: Source identification and airborne chemical characterisation of aerosol pollution from long-range transport over Greenland during POLARCAT summer campaign 2008, Atmos. Chem. Phys., 11, 1009710123, doi:10.5194/acp-11-10097-2011, 2011.

Sherwood, S. C., Roca, R., Weckwerth, T. M., and Andronova, N. G.: Tropospheric water vapor, convection, and climate, Rev. Geophys., 48, RG2001, doi:10.1029/2009rg000301, 2010.

Sinnhuber, B.-M. and Folkins, I.: Estimating the contribution of bromoform to stratospheric bromine and its relation to dehydration in the tropical tropopause layer, Atmos. Chem. Phys., 6, 4755-4761, doi:10.5194/acp-6-4755-2006, 2006.

Solomon, S., Rosenlof, K. H., Portmann, R. W., Daniel, J. S., Davis, S. M., Sanford, T. J., and Plattner, G.-K.: Contributions of Stratospheric Water Vapor to Decadal Changes in the Rate of Global Warming, Science, 327, 1219-1223, doi:10.1126/science.1182488, 2010.

Stohl, A. and James, P.: A Lagrangian analysis of the atmospheric branch of the global water cycle. part I: Method description, validation, and demonstration for the August 2002 flooding in central Europe, J. Hydrometeorol., 5, 656-678, 2004. 
Stohl, A. and Sodemann, H.: Characteristics of atmospheric transport into the Antarctic troposphere, J. Geophys. Res., 115, D02305, doi:10.1029/2009JD012536, 2010.

Stohl, A., Bonasoni, P., Cristofanelli, P., Collins, W., Feichter, J., Frank, A., Forster, C., Gerasopoulos, E., Gäggeler, H., James, P., Kentarchos, T., Kromp-Kolb, H., Krüger, B., Land, C., Meloen, J., Papayannis, A., Priller, A., Seibert, P., Sprenger, M., Roelofs, G. J., Scheel, H. E., Schnabel, C., Siegmund, P., Tobler, L., Trickl, T., Wernli, H., Wirth, V., Zanis, P., and Zerefos, C.: Stratosphere-troposphere exchange: A review, and what we have learned from STACCATO, J. Geophys. Res., 108, 8516, doi:10.1029/2002jd002490, 2003.

Stohl, A., Forster, C., Frank, A., Seibert, P., and Wotawa, G.: Technical note: The Lagrangian particle dispersion model FLEXPART version 6.2, Atmos. Chem. Phys., 5, 2461-2474, doi:10.5194/acp-5-2461-2005, 2005.

Su, H., Jiang, J. H., Liu, X., Penner, J. E., Read, W. G., Massie, S., Schoeberl, M. R., Colarco, P., Livesey, N. J., and Santee, M. L.: Observed Increase of TTL Temperature and Water Vapor in Polluted Clouds over Asia, J. Climate, 24, 2728-2736, doi:10.1175/2010jcli3749.1, 2011.

Tian, W., Chipperfield, M., and Huang, Q.: Effects of the Tibetan Plateau on total column ozone distribution, Tellus B, 60, 622635, doi:10.1111/j.1600-0889.2008.00338.x, 2008.
Tzella, A. and Legras, B.: A Lagrangian view of convective sources for transport of air across the Tropical Tropopause Layer: distribution, times and the radiative influence of clouds, Atmos. Chem. Phys., 11, 12517-12534, doi:10.5194/acp-11-12517-2011, 2011.

Vogel, B., Pan, L. L., Konopka, P., Günther, G., Müller, R., Hall, W., Campos, T., Pollack, I., Weinheimer, A., Wei, J., Atlas, E. L., and Bowman, K. P.: Transport pathways and signatures of mixing in the extratropical tropopause region derived from Lagrangian model simulations, J. Geophys. Res., 116, D05306, doi:10.1029/2010jd014876, 2011.

Vogelezang, D. H. P. and Holtslag, A. A. M.: Evaluation and model impacts of alternative boundary-layer height formulations, Bound.-Lay. Meteorol., 81, 245-269, 1996.

Werner, A., Volk, C. M., Ivanova, E. V., Wetter, T., Schiller, C., Schlager, H., and Konopka, P.: Quantifying transport into the Arctic lowermost stratosphere, Atmos. Chem. Phys., 10, 11623 11639, doi:10.5194/acp-10-11623-2010, 2010.

Wright, J. S., Fu, R., Fueglistaler, S., Liu, Y. S., and Zhang, Y.: The influence of summertime convection over Southeast Asia on water vapor in the tropical stratosphere, J. Geophys. Res., 116, D12302, doi:10.1029/2010jd015416, 2011. 